\title{
EFFECT OF DIETARY SUMAC SEED POWDER AS AN ANTIOXIDANT AND GROWTH PROMOTER ON GROWTH PERFORMANCE OF JAPANESE QUILL
}

\author{
Riry F.H. Shata and Kout Elkloub, M. EL. Moustafa \\ Anim. Prod. Res. Institute, Agric. Res. Center. Ministry of Agric. Dokki, Giza.
}

(Received 1/2 / 2017, Accepted 15/3 /2017)

\section{SUMMARY}

$\mathrm{T}$ he objective of this study was to investigate the effect of dietary sumac seed powder (SSP) as an antioxidant and growth promoter on growth performance, carcass characteristics and blood constituents. A total number of 240 Japanese quail birds 7 days old were distributed into 4 groups $(n=60)$ with 3 replicates (20 in each). The first group was fed the control $(0.0 \%$ SSP), while, the other groups fed 1.5, 2.0 and 2.5\% SSP. Body weight and feed consumption were recorded biweekly, while, mortality rate was recorded daily. Average body weight gains, feed conversion ratio, and European Production Efficiency Index (EPEI) were calculated while; bacterial count of intestinal contents was estimated. At the end of the experiment, carcass characteristics were measured, moreover, blood samples were taken to determine some blood constituents and organoleptic evaluation of cooked chicken meat. Results indicated that quail chicks fed different levels of SSP had the heaviest $(\mathrm{p}<0.05)$ body weight and body weight gain and better FCR and EPEI as compared to the control group. Sumac Seed Powder with different levels significantly $(p<0.05)$ improved dressing, breast, total edible parts and the values of the meat quality including taste, aroma, texture, color and overall acceptability compared to the control group. Abdominal fat percentage was absent with different levels of sumac compared to control group. Chicks fed 2 and 2.5\%SSP showed significantly $(\mathrm{p}<0.05)$ higher spleen, bursa and thymus. The ALT, AST, cholesterol, LDL, glucose, A/G and the population of E.coli of the control were higher than the birds fed SSP. Total antioxidants capacity, total lipids and globulin of the sumac fed groups were higher than the birds in control. Total plasma protein was significantly higher with $2 \%$ SSP compared to other treatments. Generally, diets supplemented with sumac seed powder (1.5, 2 and 2.5\%) significantly improved growth performance, carcass, meat quality and plasma blood constituents in Japanese quail. The best supplemented level of SSP was $2 \%$.

Keywords: Sumac seed, growth performance, blood constituents, Japanese quail.

\section{INTRODUCTION}

There has been a global trend toward the use of natural substances present in fruits, vegetables, and herbs as an anti-oxidants and functional foods (Lee et al., 1999). In addition, several of these substances are believed to have potential value as cancer chemo preventive or therapeutic agents in vivo. Some vitamins and their derivatives have important biological roles related to cancer prevention and free radical scavenging (van Poppel and van den Berg, 1997), in addition to the presence of some phytochemicals, such as taxol (Mukherjee et al., 2001), oncovin and captothecin which are currently used in cancer treatment.

Sumac (Rhus coriaria L.) belongs to Anacardiaceous family and it grows widely in Asian countries. The fruits of sumac contain flavonols, phenolic acids, hydrolysable tannins, anthocyans and organic acids such as malice, citric and tartaric acids (Özcan \& Haciseferogullari, 2004). Sumac seeds are rich in B vitamins and also gallic, benzoic and L-ascorbic acids (Abas 2009). The seeds of sumac are a very good source of gallotannis, volatile oil, anthocyanin (Guvenc and Koyuncu, 1994), flavones, such as myricetin quercetin and kaempferol (Mehrdad et al., 2009), nitrite and nitrate contents (Ozcan and Akbulut, 2007).

Sumac is effective against both gram positive and negative bacteria, but it is more effective on gram positive than gram negative microorganisms (Ahmadian-attari et al., 2007). The antimicrobial and antifungal activity is likely to be associated with the high concentration of $\alpha$-pinene $(86.95 \%)$ of total 
essential oil. The antioxidant effect may be due to the monoterpenes $\alpha$-pinene which acts as a radical scavenging agent. Sumac (Rhus lancea) contain essential oils protects against genotoxic carcinogens so it has DNA protective effect due to endogenous production of oxidized pyrimidines and purines (Chakraborty et al., 2009). Phenolic compounds that are found in sumac inhibit lipid peroxidation, scavenge the superoxide anion and hydroxyl radical (Khalaf et al., 2008) and enhance the activities of detoxifying enzymes such as glutathione-S-transferase (Zavaragh, 2011). D-limonene (1-methyl-4-(1methylethenyl)-cyclohexane) is a monocyclic monoterpene component of sumac that has hypocholesterolemic effects (Kurucu et al., 1993).

Mansoub (2011) reported that when used sumac powder in broiler diet at levels $0.75,1,1.5,2 \%$ the highest percent of breast, thigh and HDL were observed at level $2 \%$ and the lowest percent of abdominal fat and LDL was observed at level $1.5 \%$. While, the highest dressed carcass belonged to diet contained $0.05 \%$ sumac powder and less abdominal fat, also increased liver weight as compared to control diet (Mohammadi et al., 2011). Golzadeh, et al. (2012) found that dietary supplementation of sumac fruit powder reduces the total cholesterol, very low density lipoprotein and plasma fasting blood sugar.

Kheiri et al. (2015) found that feeding chicks by sumac powder and dried whey powder each of $0.02 \%$ increased feed intake, body weight gain and antibody level as well as the titer against Newcastle disease compared to the control group and significantly decreased the serum concentration of triglycerides and cholesterol. While low-density lipoprotein level significantly decreased and high-density lipoprotein levels increased in the sumac group. Also, E. coli population decreased while Lactobacillus and intestinal morphology increased in broiler chicks receiving the sumac and dried whey powder. Undoubtedly, sumac is considered as herbal plant have a wide range of potential use so, the objective of this study was to explore the potential uses of sumac seed powder as growth promoter on performance of Japanese quail at the period of 7-42 days.

\section{MATERIALS AND METHODS}

The present experiment was carried out at El - Fayoum Poultry Farm, Animal Production Research Institute, Agriculture Research Center, Ministry of Agriculture, Egypt.

\section{Experimental birds and design}

A total of 240 unsexed birds of Japanese quail 7 days old having nearly equal live weights (32g) were distributed randomly into 4 treatment groups. Sixty birds were assigned to each treatment group, 3 replicates per each, each containing 20 birds. Birds in all treatments were fed basal diet with $24 \% \mathrm{CP}$ and $2900 \mathrm{Kcal}$ (Table1). The sumac seed was purchased from local market and grounded separately to a fine powder and then mixed with the basal diet. Dietary treatments were designed to contain 0.0 (control), 1.5, 2.0 and $2.5 \%$ sumac seed powder (SSP) as growth promoter in Japanese quail. Feed and water were supplied ad libitum throughout experimental period while ended at $42 \mathrm{wks}$ of age. Body weight (BW) and feed consumption (FC) were recorded biweekly, while, mortality rate was recorded daily and average body weight gains (BWG), feed conversion ratio (FCR) were calculated. The bacterial count of intestinal contents was estimated, in addition to European Production Efficiency Index (EPEI) was calculated.

EPEI $=$ BW $(\mathrm{kg}) \times \mathrm{LA} \times 100 / \mathrm{PP} \times$ FCR.

Where: BW: Body weight $(\mathrm{kg}), \quad$ LA: Livability (100-\% mortality)

PP: Production period (days), FCR: Feed conversion ratio (kg feed / kg gain).

At the end of the experiment, three birds from each treatment were randomly taken and slaughtered to obtain the carcass; giblets (gizzard, liver and heart) and the lymphoid organs were separately weighed. Meat quality evaluation of cooked chicken was done. Blood samples were taken to determine plasma content of total protein, albumin, globulin, total lipids, glucose, cholesterol (HDL- LDL), total antioxidants capacity, calcium, phosphorus and liver enzymatic activity (AST and ALT)using commercial kits.

Obtained data were statistically analyzed using one-way linear model procedure described in SAS user guide (SAS, 1990). Differences among means were tested using Duncan's multiple range test (Duncan's, 1955). One - way analysis model applied was:

$$
\begin{gathered}
Y_{i j}=\mu+T_{i}+E_{i j} \quad \text { Where: } Y_{i j}=\text { Observations, } \mu=\text { the overall mean, } \\
T i=\text { Effect of } i^{\text {th }} \text { treatments }(0.0,1.5,2.0 \text { and } 2.5 \% \text { SSP }), \quad E_{i j}=\text { Experimental error }
\end{gathered}
$$


Table (1): Composition and calculated analysis of experimental diets.

\begin{tabular}{|c|c|c|c|c|}
\hline \multirow{2}{*}{$\begin{array}{l}\text { Ingredient } \\
\text { Sumac seed powder (SSP) }\end{array}$} & \multicolumn{4}{|c|}{ Different levels of SSP \% } \\
\hline & 0.0 & 1.5 & 2.0 & 2.5 \\
\hline Yellow corn & 52.67 & 50.47 & 49.93 & 49.43 \\
\hline Soybean meal $44 \%$ & 37.61 & 36.57 & 35.93 & 35.23 \\
\hline Corn gluten meal & 5.50 & 6.50 & 7.00 & 7.50 \\
\hline Soya oil & 1.20 & 1.90 & 2.05 & 2.25 \\
\hline Dicalcium phosphate & 0.82 & 0.82 & 0.83 & 0.83 \\
\hline Limestone & 1.47 & 1.47 & 1.47 & 1.47 \\
\hline $\mathrm{NaCl}$ & 0.33 & 0.33 & 0.33 & 0.33 \\
\hline Premix*(V\&M.) & 0.30 & 0.30 & 0.30 & 0.30 \\
\hline DL. Methionine & 0.07 & 0.07 & 0.06 & 0.06 \\
\hline L. Lysine $\mathrm{HCl}$ & 0.03 & 0.07 & 0.10 & 0.10 \\
\hline Total & 100 & 100 & 100 & 100 \\
\hline \multicolumn{5}{|l|}{ Calculated values \% } \\
\hline $\mathrm{CP} \%$ & 24 & 24 & 24 & 24 \\
\hline $\mathrm{ME} . \mathrm{KCal} / \mathrm{Kg}$ & 2900 & 2900 & 2900 & 2900 \\
\hline $\mathrm{Ca} \%$ & 0.80 & 0.80 & 0.80 & 0.80 \\
\hline Avail. P\% & 0.30 & 0.30 & 0.30 & 0.30 \\
\hline Methionine \% & 0.50 & 0.50 & 0.50 & 0.50 \\
\hline Lysine\% & 1.30 & 1.30 & 1.30 & 1.30 \\
\hline Meth. +cyst. & 0.75 & 0.75 & 0.75 & 0.75 \\
\hline $\mathrm{Na}$ & 0.22 & 0.22 & 0.22 & 0.22 \\
\hline
\end{tabular}

\section{RESULTS AND DISCUSSION}

\section{Productive performance}

\section{Live body weight and body weight gain}

Effect of feeding dietary inclusion levels of sumac seed powder (SSP) being 0.0, 1.5, 2 and 2.5\% in Japanese quail chick diets on live body weight (BW) and body weight gain (BWG) are presented in Table (2). The results indicated that BW and BWG of chicks fed all levels of SSP $(0.0,1.5,2$ and $2.5 \%)$ in all growth periods were significantly $(\mathrm{p}<0.05)$ higher than the control group, except the period of 29-42 day which recorded the higher numerical BWG $(1.5$ and $2.5 \% \mathrm{SSP})$ than the control group. The improvement of BW and BWG may be due to the active materials (Phenolic compounds, organic acids, B vitamins, ascorbic acids, anthocyans ,.....etc) found in sumac, causing greater efficiency in the utilization of feed, resulting in enhanced growth. Improving feed utilization by using sumac seed powder probably due to its anti-bacterial effect on gut microflora (Ahmadian-attari et al.,2007) and the finding of Mansoub (2011) who showed that using different levels of sumac $(0.75,1.0,1.5$ and $2 \%)$ had significant effect on weight gain in broiler compared to the control group. Also, Zavaragh (2011) showed that $2 \%$ garlic, $2 \%$ sumac and $2 \%$ garlic + sumac powder improved the average daily gain of Japanese quails compared to the control group. The same observation was noted by Valiallahi et al.(2014)who revealed that total body weight and body weight gain significantly increased by feeding diets contained sumac powder at $0.02 \%$ compared to $0.02 \%$ ajwain powder , $0.02 \%$ virginiamycin powder and control group. Kheiri et al. (2015) found that either $0.02 \%$ sumac powder, or $0.02 \%$ dried whey powder, had significantly $(\mathrm{P}<0.05)$ increased body weight gain compared to the control. In addition, Sharbati et al. (2013) found that no significant differences between the treatments for BWG during whole the experimental period when used different levels of sumac seed powder $(0,0.25,0.5$ and $1 \%)$ or $100 \mathrm{mg} / \mathrm{kg}$ alpha tocopherol acetate (Vitamin E) of broiler under heat stress condition. while, Golzadeh et al. (2012) reported that no adverse effect had been observed on BWG when used sumac $(2.5,5$ and $10 \mathrm{~g} / \mathrm{kg})$. These results were not agreed with the report of Mahammadi et al. (2011) regarding effect of sumac on BWG. 
No mortality observed among all the SSP inclusion levels in the diets, while, control group recorded two died chicks (Table 2). Generally, the viability of all birds during the experimental period was improved by SSP supplementation

Table (2): Effect of dietary sumac seed powder (SSP) at different levels on Japanese quail body weight, body weight gain and mortality rate.

\begin{tabular}{lccccccccc}
\hline Item & \multicolumn{4}{c}{ Body weight $(\mathrm{g})$} & \multicolumn{3}{c}{ Body weight gain $(\mathrm{g})$} & \multicolumn{3}{c}{ Morality } \\
\cline { 2 - 10 } & $7 \mathrm{~d}$ & $14 \mathrm{~d}$ & $28 \mathrm{~d}$ & $42 \mathrm{~d}$ & $7-14 \mathrm{~d}$ & $15-28 \mathrm{~d}$ & $29-42 \mathrm{~d}$ & $7-42 \mathrm{~d}$ & $7-42 \mathrm{~d}$ \\
\hline Control & 32.59 & $69.18 \mathrm{c}$ & $161.56 \mathrm{~b}$ & $233.32 \mathrm{c}$ & $36.50 \mathrm{c}$ & $92.38 \mathrm{~b}$ & $71.77 \mathrm{~b}$ & $200.74 \mathrm{c}$ & 2 \\
SSP1.5\% & 32.59 & $79.69 \mathrm{a}$ & $193.13 \mathrm{a}$ & $270.40 \mathrm{ab}$ & $47.11 \mathrm{a}$ & $113.44 \mathrm{a}$ & $77.27 \mathrm{ab}$ & $237.81 \mathrm{ab}$ & 0 \\
SSP2.0\% & 32.58 & $80.13 \mathrm{a}$ & $200.97 \mathrm{a}$ & $283.32 \mathrm{a}$ & $47.55 \mathrm{a}$ & $120.84 \mathrm{a}$ & $82.35 \mathrm{a}$ & $250.74 \mathrm{a}$ & 0 \\
SSP2.5\% & 32.59 & $74.20 \mathrm{~b}$ & $188.15 \mathrm{a}$ & $263.03 \mathrm{~b}$ & $41.61 \mathrm{~b}$ & $113.94 \mathrm{a}$ & $74.89 \mathrm{ab}$ & $230.44 \mathrm{~b}$ & 0 \\
SEM & \pm 0.01 & \pm 0.57 & \pm 4.62 & \pm 4.07 & \pm 0.50 & \pm 4.40 & \pm 1.90 & \pm 4.07 & - \\
\hline
\end{tabular}

$a, b, c$ Means in the same row with different superscripts are significantly different $(p \leq 0.05)$

\section{Feed consumption and feed conversion ratio:}

Data of feed consumption (FC) and feed conversion ratio (FCR) obtained by using SSP in the chicks diets are listed in Table (3). The average values of FC for chicks fed the control diet recorded significantly lower FC than $2 \%$ SSP during all periods. While, no significant differences in FC were observed between 1.5, 2.5 and control group at all periods.

Table (3): Effect of dietary sumac seed powder (SSP) at different levels on Japanese quail feed consumption, feed conversion ratio and European Production Efficiency Index (EPEI).

\begin{tabular}{lccccccccc}
\hline Treatments & \multicolumn{3}{c}{ Feed consumption (g/bird) } & \multicolumn{3}{c}{ Feed conversion ratio } & \multicolumn{2}{c}{ EPEI \% } \\
\cline { 2 - 9 } & $7-14 \mathrm{~d}$ & $15-28 \mathrm{~d}$ & $29-42 \mathrm{~d}$ & $7-42 \mathrm{~d}$ & $7-14 \mathrm{~d}$ & $15-28 \mathrm{~d}$ & $29-42 \mathrm{~d}$ & $7-42 \mathrm{~d}$ & $7-42 \mathrm{~d}$ \\
\hline Control & 99.00 & $258.20^{\mathrm{c}}$ & $327.01^{\mathrm{b}}$ & $684.21^{\mathrm{b}}$ & $2.70^{\mathrm{a}}$ & $2.81^{\mathrm{a}}$ & 4.57 & $3.41^{\mathrm{a}}$ & $16.13^{\mathrm{b}}$ \\
SSP 1.5\% & 96.33 & $292.42^{\mathrm{ab}}$ & $335.87^{\mathrm{ab}}$ & $724.61^{\mathrm{ab}}$ & $2.04^{\mathrm{c}}$ & $2.58^{\mathrm{ab}}$ & 4.35 & $3.05^{\mathrm{b}}$ & $21.13^{\mathrm{a}}$ \\
SSP 2.0\% & 95.24 & $297.72^{\mathrm{a}}$ & $355.56^{\mathrm{a}}$ & $748.52^{\mathrm{a}}$ & $2.00^{\mathrm{c}}$ & $2.47^{\mathrm{ab}}$ & 4.32 & $2.99^{\mathrm{b}}$ & $22.62^{\mathrm{a}}$ \\
SSP 2.5\% & 98.22 & $264.24^{\mathrm{bc}}$ & $319.93^{\mathrm{b}}$ & $682.40^{\mathrm{b}}$ & $2.36^{\mathrm{b}}$ & $2.32^{\mathrm{b}}$ & 4.28 & $2.96^{\mathrm{b}}$ & $21.17^{\mathrm{a}}$ \\
SEM & \pm 3.38 & \pm 9.42 & \pm 7.29 & \pm 14.98 & \pm 0.08 & \pm 0.11 & \pm 0.10 & \pm 0.06 & \pm 0.59 \\
\hline
\end{tabular}

$a, b, c$ Means in the same row with different superscripts are significantly different $(p \leq 0.05)$.

Significantly, better feed conversion ratio (FCR) was obtained by using the different levels of SSP compared to the control group at 7-14 and 7-42 day of age. At 15-28 days the chicks fed 2.5\% recorded significantly the best FCR compared to the control group, in spite of the numerical differences found between all levels of SSP and the control group at the same period. The improvement noticed in FCR for chick groups treated with different levels of sumac may refer either to improvement of BWG compared to the control group, or decreasing the population of $E$. coli consequently, BW and BWG improved. Results obtained are in harmony with those obtained by Mansoub (2011) who showed that using different levels of sumac had significant effect on feed intake and FCR in broilers compared to the control group. Also, Zavaragh (2011) reported that $2 \%$ garlic, $2 \%$ sumac and $2 \%$ garlic + sumac powder improved $(\mathrm{p}<0.05)$ feed intake and FCR of Japanese quails compared to the control group. Golzadeh et al. (2012) found that feed intake of $10 \mathrm{~g}$ sumac $/ \mathrm{kg}$ feed was significantly higher and FCR significantly improved compared to that of the control and $2.5 \mathrm{~g}$ sumac. The same observation was noted by Valiollahi et al. (2014) who revealed that feed intake significantly $(\mathrm{P}<0.05)$ increased and FCR significantly improved in treated groups $(0.02 \%$ sumac, $0.02 \%$ ajwain and $0.02 \%$ virginiamycin) compared to the control group. Kheiri et al. (2015) found that either $0.02 \%$ sumac, or $0.02 \%$ dried whey, had significantly $(\mathrm{P}<0.05)$ reduced FC, while, FCR improved compared to the control. Sharbati et al. (2013) found that no significant differences between the treatments for feed intake during whole the experimental period when used different levels of SSP $0,0.25,0.5$ and $1 \%$ or $100 \mathrm{mg} / \mathrm{kg}$ vit. E of broilers. High trend was observed for FCR of vit. E and $0.5 \%$ sumac fed chickens as compared to other birds. These results were not agreed with the report of Mahammadi et al. (2011) regarding effect of sumac on feed intake, while, the best level of sumac was 0.15 for FCR. 
The effect of feeding dietary inclusion levels of SSP $1.5,2$ and $2.5 \%$ on the technical evaluation expressed as European Production Efficiency Index (EPEI) is presented in Table 3. It was cleared that chicks fed diets supplemented with SSP (1.5, 2 and 2.5\%) recorded significantly higher EPEI value than those fed control group. While, 2\% SSP was recorded the highest value compared to the other treatments. This result may be due to the increasing of BW and improving FCR and livability.

\section{Carcass characteristics}

The effect of different levels of sumac powder on carcass traits of Japanese quail chicks at 42 days of age are listed in Table (4). Application of different levels of SSP had significant differences on carcass traits $(\mathrm{p}<0.05)$ except thigh and liver percentages. The highest $(\mathrm{p}<0.05)$ percentage of dressing and total edible parts were observed in all levels of sumac compared to the control group. While, the higher percentage of breast was observed at levels 1.5 and 2\% SSP compared to the 2.5\% SSP and control group. On the other hand, higher $(\mathrm{p}<0.05)$ percentage of gizzard and giblets were observed in the control compared to the levels 1.5 and 2\% SSP. Abdominal fat percentage was absent in all levels of SSP compared to control group. But, $2.5 \%$ SSP significantly $(\mathrm{P}<0.05)$ increased heart percentage compared to the other treatments.

Table (4): Effect of dietary sumac seed powder (SSP) on carcass characteristics and lymphoid organs of Japanese quail at 42 days old.

\begin{tabular}{lccccc}
\hline Item & \multicolumn{4}{c}{ sumac seed powder \% } & SEM \\
\cline { 2 - 5 } & Control & SSP1.5\% & SSP2.0\% & SSP2.5\% & \pm 10.64 \\
Live weight(g) & 215 & 218.00 & 212.33 & 217.00 & \\
Carcass characteristics \% & & & & $74.09^{\mathrm{a}}$ & \pm 0.31 \\
Dressing & $72.31^{\mathrm{b}}$ & $74.51^{\mathrm{a}}$ & $74.24^{\mathrm{a}}$ & $42.59^{\mathrm{b}}$ & \pm 0.49 \\
Breast & $43.42^{\mathrm{b}}$ & $45.56^{\mathrm{a}}$ & $45.90^{\mathrm{a}}$ & 24.44 & \pm 0.64 \\
Thigh & 25.01 & 25.09 & 24.40 & 0.00 & \pm 0.003 \\
Abdominal fat & 0.40 & 0.00 & 0.00 & $1.79^{\mathrm{ab}}$ & \pm 0.11 \\
Gizzard & $1.98^{\mathrm{a}}$ & $1.57^{\mathrm{b}}$ & $1.47^{\mathrm{b}}$ & 2.18 & \pm 0.17 \\
Liver & $2.21^{\mathrm{a}}$ & 2.08 & $2.16^{\mathrm{a}}$ & $0.82^{\mathrm{b}}$ & \pm 0.02 \\
Heart & $0.89^{\mathrm{a}}$ & $0.93^{\mathrm{a}}$ & $0.94^{\mathrm{a}}$ & $4.89^{\mathrm{ab}}$ & \pm 0.13 \\
Giblets* & $5.08 \mathrm{a}^{\mathrm{a}}$ & $4.58^{\mathrm{b}}$ & $4.57^{\mathrm{b}}$ & $78.87^{\mathrm{a}}$ & \pm 0.32 \\
Total edible parts** & $77.38^{\mathrm{b}}$ & $79.09^{\mathrm{a}}$ & $78.81^{\mathrm{a}}$ & & \\
lymphoid organs\% $_{\text {Spleen }}$ & & & & & \\
Bursa & $0.063^{\mathrm{b}}$ & $0.073^{\mathrm{ab}}$ & $0.079^{\mathrm{a}}$ & $0.082^{\mathrm{a}}$ & \pm 0.004 \\
Thymus & $0.097^{\mathrm{b}}$ & $0.104^{\mathrm{b}}$ & $0.125^{\mathrm{a}}$ & $0.139^{\mathrm{a}}$ & \pm 0.005 \\
\hline
\end{tabular}

$a, b$ Means in the same row with different superscripts are significantly different $(p \leq 0.05)$.

* Giblets $=$ gizzard $=$ liver $=$ heart.

In conformity, results obtained agreed with those reported by Mansoub (2011) who used 0.75, 1, 1.5 and $2 \%$ sumac and found higher percentages of breast and thigh in 1.5 and $2 \%$ sumac and the lowest percent of abdominal fat was observed in $1.5 \%$ sumac group. Also, Mahammadi et. al. (2011) concluded that, feeding $0.05,0.1$ and $0.15 \%$ sumac produced higher carcass and less abdominal fat. Zavaragh (2011) showed that application of different levels of sumac and garlic (2\% garlic, $2 \%$ sumac and 2\% garlic $+2 \%$ sumac) significantly affected the carcass traits. Kheiri et al. (2015) found that either $0.02 \%$ sumac or 0.02 $\%$ dried whey significantly $(\mathrm{P}<0.05)$ reduced abdominal fat compared to the control. Adding sumac as an antimicrobial agent may decrease the amount of intestinal colony and prevent lysis of amino acids which will be consumed in formation of protein tissues and increased the breast percentage. In contrast, no beneficial effect of dietary supplementation of different sumac levels was observed on carcass characteristics including proportional weights of thigh, breast, abdominal fat, liver and heart as reported by Sharbati et al. (2013).

The effect of different levels of SSP on lymphoid organs percentage is shown in Table 4. Application of different levels of SSP significantly affected the lymphoid organs $(\mathrm{p}<0.05)$. The current results demonstrated that spleen, bursa and thymus relative weights significantly increased with 2 and 2.5\% SSP compared to control group and 1.5\% SSP. On contrary, Kheiri et al. (2015) found that either $0.02 \%$ sumac or $0.02 \%$ whey powder significantly $(\mathrm{P}<0.05)$ reduced burse of fabrieius percentage, while, spleen percentage was significantly increased $(\mathrm{p}<0.05)$ compared to the control group. 


\section{Blood constituents}

Biochemical parameters of blood plasma have been used as an indicator of the nutritional and physiological status of chicks. The analysis of variance indicated that Japanese quail chicks fed diets supplemented with SSP numerically recorded the best levels of plasma contents of calcium, phosphorous and albumin compared to control group (Table 5), whereas, plasma ALT of the control group was significantly higher than that of the 1.5 and $2 \%$ SSP birds $(\mathrm{p}<0.05)$. Plasma AST of the $1.5 \%$ SSP birds was significantly lower than that of the $2.5 \% \mathrm{SSP}$ and the control group. Also, the plasma total cholesterol, LDL, glucose and A/G ratio of all levels of SSP birds were lower $(p<0.05)$ than that of the control group. Furthermore, the HDL concentration of the control group and $1.5 \%$ SSP birds was higher $(\mathrm{p}<0.05)$ than that of 2 and $2.5 \%$ SSP. The concentrations of total antioxidants capacity and total lipids values in plasma were significantly high in $2 \%$ followed by $1.5 \%$ and $2.5 \%$ SSP compared to control group (Table 5). Total protein and globulin were significant higher $(\mathrm{p}<0.05)$ for birds fed 2 and $2.5 \%$ SSP compared to the $1.5 \%$ SSP and the control group.

Table (5): Effect of dietary sumac seed powder on some blood constituents of Japanese quail at 42 days old.

\begin{tabular}{|c|c|c|c|c|c|}
\hline \multirow[t]{2}{*}{ Item } & \multicolumn{4}{|c|}{ Sumac seed powder (SSP)\% } & \multirow{2}{*}{ SEM } \\
\hline & Control & SSP1.5\% & SSP2.0\% & SSP2.5\% & \\
\hline Calcium(mg/dl) & 9.83 & 10.11 & 10.13 & 10.11 & \pm 0.18 \\
\hline Phosphorus(g/dl) & 2.29 & 2.40 & 2.38 & 2.46 & \pm 0.11 \\
\hline $\operatorname{ALT}(\mathrm{U} / \mathrm{L})$ & $48.67^{\mathrm{a}}$ & $40.33^{\mathrm{b}}$ & $40.00^{\mathrm{b}}$ & $44.33^{\mathrm{ab}}$ & \pm 1.78 \\
\hline AST (U/L) & $12.33^{\mathrm{a}}$ & $9.67^{\mathrm{b}}$ & $11.67^{\mathrm{a}}$ & $11.33^{\mathrm{ab}}$ & \pm 0.53 \\
\hline Cholesterol(mg/dl) & $198.37^{\mathrm{a}}$ & $175.57^{\mathrm{b}}$ & $154.56^{\mathrm{c}}$ & $169.52^{\mathrm{bc}}$ & \pm 5.36 \\
\hline HDL- Cholesterol(mg/dl) & $51.14^{\mathrm{a}}$ & $49.63^{\mathrm{a}}$ & $39.23^{\mathrm{b}}$ & $41.11^{\mathrm{b}}$ & \pm 2.24 \\
\hline LDL- Cholesterol(mg/dl) & $147.23^{\mathrm{a}}$ & $125.93^{\mathrm{b}}$ & $115.32^{\mathrm{b}}$ & $128.41^{\mathrm{b}}$ & \pm 4.77 \\
\hline Total antioxidants capacity $(\mathrm{mmol} / \mathrm{l})$ & $0.532^{\mathrm{c}}$ & $0.587^{\mathrm{b}}$ & $0.607^{\mathrm{a}}$ & $0.580^{\mathrm{b}}$ & \pm 0.01 \\
\hline $\mathrm{T}$.lipids (mg/dl) & $460.85^{\mathrm{c}}$ & $548.37^{\mathrm{ab}}$ & $561.55^{\mathrm{a}}$ & $500.08^{b c}$ & \pm 15.21 \\
\hline Glucose (mg/dl) & $155.1^{\mathrm{a}}$ & $129.78^{\mathrm{b}}$ & $123.33^{\mathrm{b}}$ & $98.17^{\mathrm{c}}$ & \pm 2.79 \\
\hline T. $\operatorname{protein}(\mathrm{g} / \mathrm{dl})$ & $4.31^{\mathrm{bc}}$ & $3.95^{\mathrm{c}}$ & $4.80^{\mathrm{a}}$ & $4.66^{\mathrm{ab}}$ & \pm 0.14 \\
\hline Albumin $(\mathrm{A})(\mathrm{g} / \mathrm{dl})$ & 2.06 & 1.67 & 1.81 & 1.87 & \pm 0.12 \\
\hline Globulin $(\mathrm{G})(\mathrm{g} / \mathrm{dl})$ & $2.26^{\mathrm{b}}$ & $2.2^{\mathrm{b}}$ & $2.99^{\mathrm{a}}$ & $2.79^{\mathrm{a}}$ & \pm 0.11 \\
\hline $\mathrm{A} / \mathrm{G}$ ratio & $0.93^{\mathrm{a}}$ & $0.74^{\mathrm{ab}}$ & $0.61^{\mathrm{b}}$ & $0.67^{\mathrm{b}}$ & \pm 0.07 \\
\hline
\end{tabular}

$a, b, c$ Means in the same row with different superscripts are significantly different ( $p \leq 0.05)$.

Similar results have been obtained by Mansoub (2011) who showed that the serum total cholesterol, triglycerides and LDL were significantly reduced, while, glucose and HDL were significantly induced in treatment groups $(0.75,1,1.5$ and $2 \%$ SSP) compared to the control $(p<0.05)$. Also, Zavaragh (2011) showed that serum total cholesterol and triglycerides concentration were significantly reduced in $2 \%$ sumac compared to the control group $(\mathrm{P}<0.05)$. Also, Golzadeh et al. (2012) found that total cholesterol of birds fed $5 \mathrm{~g}$ and $10 \mathrm{~g}$ sumac/kg was significantly lower than that of the control and $2.5 \mathrm{~g}(\mathrm{p}<0.05)$. Moreover, no significant differences were obtained between the treatments for plasma HDL and LDL than those of the other treatments $(\mathrm{p}<0.05)$, the plasma fasting blood sugar of $10 \mathrm{~g} / \mathrm{kg}$ was lower $(\mathrm{p}<0.05)$ than control and 2.5g. Also, Valiollahi et al. (2014) revealed that blood triglycerides, total cholesterol and LDL decreased significantly at $0.02 \%$ sumac powder, while HDL significantly increased compared to the other treatments. Kheiri et al. (2015) found that the serum cholesterol and LDL concentration of chicks decreased significantly by sumac and whey powder feeding, while, HDL levels increased in the sumac group compared to the control group. These results may be due to hypocholesterolemic effects of sumac which contain d-limonene (1-methyl-4-1-methyletheny 1-cyclohexane) as a monocyclic monoterpene component. The hypocholesterolemic action of sumac is possibly related to its polyphenolic components. Poly phenols have been shown to depress the reverse-cholesterol transport, reduce the intestinal cholesterol absorption and even increase bile acid excretion (Jung, 1998). Also, free gallbladder acids attached to bacteria and fibers and this can increase the excretion of them. This is consistent with the well-observed effect of herbs on lowering blood cholesterol level. On contrary, Sharbati et al. (2013) found that the blood total protein of either sumac or vitamin E fed birds was lower than that of control 
birds $(\mathrm{P}<0.05)$. None of blood cholesterol, triglycerides and hemoglobin was affected by dietary treatments.

\section{Ceca microbial content}

The number of colony - forming units per gram of ceca revealed more distinct differences (Table 6). The addition of different levels of SSP reduced significantly $(\mathrm{p}<0.05)$ the population of E. coli compared to the control group. On the other hand, no differences $(\mathrm{p}<0.05)$ were observed in lactobacillus count between treatment groups.

Table (6): Effect of dietary sumac seed powder (SSP) on ceca microbial content of Japanese quail at 42 days old.

\begin{tabular}{lcc}
\hline Treatments & Lactobacillus & E.Coli \\
\hline Control & More than $300 \mathrm{cfu}$ & $12130 \times 10^{5 \mathrm{a}}$ \\
SSP 1.5\% & More than 300 cfu & $830.0 \times 10^{5 \mathrm{~b}}$ \\
SSP 2.0\% & More than 300 cfu & $0.44 \times 10^{5 \mathrm{c}}$ \\
SSP 2.5\% & More than 300 cfu & $15.0 \times 10^{5 \mathrm{~d}}$ \\
SEM & - & \pm 66.72 \\
\hline
\end{tabular}

$a, b, c, d$ Means in the same row with different superscripts are significantly different $(P \leq 0.05)$.

Researchers suggested that sumac and probiotic can control microbial growth by acting on the microflora's biochemical processes such as protein synthesis or inhibiting the elongation of Methanobacterium and Escherichia coli, or by reducing lactic acid producing bacteria in the gastrointestinal tract (Guvenc and Koyuncu, 1994). Jung (1998) indicated that sumac is effective against both gram-positive and gram-negative bacteria, while it is more effective on gram-positive than gramnegative microorganisms. In this connection, Mansoub (2011) found that antimicrobial substances present in sumac and cinnamon can reduce the harmful bacteria populations in the gastrointestinal tract and improve the levels of absorbed amino acids. Also, Valiollahi et al. (2014) revealed that the population of E. coli decreased significantly while lactobacillus increased significantly in treated groups $(0.02 \%$ sumac powder, $0.02 \%$ ajwain powder and $0.02 \%$ virginiamycin powder) compared to control group. Kheiri et al. (2015) investigated that E. coli population decreased while Lactobacillus increased in sumac and whey powder groups compared to the control.

The effects of sumac seed powder on the organoleptic properties of the cooked Japanese quail chick's meat

Effects of different levels of SSP on the organoleptic properties of the Japanese quail chick's meat are shown in Table (7).

Table (7): Effect of dietary sumac seed powder (SSP) on the sensory properties of the cooked chicken meat of Japanese quail at 42 days old.

\begin{tabular}{lccccc}
\hline Treatments & Color & Taste & Aroma & Texture & Overall acceptability \\
\hline Control & $8.20^{\mathrm{b}}$ & $7.60^{\mathrm{b}}$ & $8.07^{\mathrm{b}}$ & $8.30^{\mathrm{b}}$ & $7.77^{\mathrm{b}}$ \\
SSP $1.5 \%$ & $8.27^{\mathrm{b}}$ & $9.30^{\mathrm{a}}$ & $8.70^{\mathrm{a}}$ & $8.77^{\mathrm{a}}$ & $8.77^{\mathrm{a}}$ \\
SSP 2.0\% & $8.93^{\mathrm{a}}$ & $8.53^{\mathrm{a}}$ & $9.0^{\mathrm{a}}$ & $8.93^{\mathrm{a}}$ & $9.0^{\mathrm{a}}$ \\
SSP 2.5\% & $8.60^{\mathrm{ab}}$ & $8.57^{\mathrm{a}}$ & $8.77^{\mathrm{a}}$ & $8.80^{\mathrm{a}}$ & $8.77^{\mathrm{a}}$ \\
SEM & \pm 0.15 & \pm 0.16 & \pm 0.14 & \pm 0.16 & \pm 0.12 \\
\hline
\end{tabular}

$a, b$ Means in the same row with different superscripts are significantly different $(P \leq 0.05)$.

Very good: 8-9, good: 6-7, fair: 4-5, poor: 1-3.

The addition of $2 \%$ SSP in chicks diets significantly $(\mathrm{p}<0.05)$ improved the meat color compared to $1.5 \%$ SSP and the control group, however, the addition of SSP at different levels in Japanese quail diets significantly $(\mathrm{p}<0.05)$ improved values of the meat taste, aroma, texture and overall acceptability compared to the control group. 


\section{CONCLUSION}

Under our experimental conditions, dietary supplementation of sumac seed powder at levels of 1.5,2 and $2.5 \%$ could be used safely in Japanese quail diets to enhance the growth performance, produce healthy broilers with a higher immune status to fight against enteric pathogens, absence of abdominal fat and improved blood cholesterol profile. Generally, the best level was $2 \%$ SSP.

\section{REFERENCES}

Abas, K. A. (2009). Using of non-traditional plants and spices in broiler nutrition: PhD. Thesis. Nitra: Slovak University of Agriculture.

Ahmadian-attari, M.M., Amin, G.H., Fazeliand, M.R. and Jamalifar, H. (2007). A review on the antibacterial and effects of sumac fruit. Medicinal Plants.,7(1): 1-9.

Chakrabortya, A., Ferka, F., Simić, T., Brantnerb, A., Dusinšká, M., Kundid, M., Christine, H., Nersesyan, A. \& Knasmuller, S. (2009). DNA-protective effects of sumach (Rhus coriaria L.), a common spice: results of human and animal studies. Mutat. Res. 661, 10-17.

Duncan, D.B. (1955). Multiple Range and Multiple F-Tests. Biometrics, 11:1-42.

Golzadeh M., Farhoomand P. \& Daneshyar M. (2012). Dietary Rhus coriaria L. powder reduces the blood cholesterol, VLDL-c and glucose, but increases abdominal fat in broilers South African J. of Anim. Sci., 42 (No. 4).

Guvenc, A. and Koyuncu, M. (1994). A study on the main active compounds of leaves and fruits of Rhus coriaria L. In Turkish J. Med. Sci., 20, (1) 11-13.

Jung N. C. (1998) Biological activity of urushiol and flavanoid from Lac tree (Rhus verniciflua Stokes), $\mathrm{PhD}$ Thesis Chonnam National University, Kwang-Ju, South Korea.

Khalaf, N. A., Shakya, A.K., Al-Othman, A., El-Agbar, Z. and Farah, H.(2008). Antioxidant Activity of Some Common Plants. Turkish J. Biol. 32: 51-55.

Kheiri F., Rahimian Y. and Nasr J. (2015) Application of sumac and dried whey in female broiler feed. Arch. Anim. Breed., 58, 205-210.

Kurucu, S., Koyuncu, M., Guvenc, A., Baser, K.H.C. and Ozek, T. (1993). The essential oil of Rhus coriaria L. (sumac). J. Essent. Oil Res: Jeor. 5: 481-486.

Lee, T. E., Park, S. W. and Min, T. J. (1999) Antiproliferative effect of Artemisia argyi extract against J774A.1 cells and subcellular superoxide dismutase (SOD) activity changes. J. Biochem. Mol. Biol. $32,585-593$.

Mansoub N. H. (2011). Effect of different levels of Sumac Powder (Rhus Coriaria L.) on performance, carcass and blood parameters of broiler Chickens. Annals of Biological Research, 2 (5):647-652

Mehrdad M, Zebardast M, Abedi G, Koupaei MN, Rasouli H and Talebi M. (2009). Validated high throughput HPLC method for the analysis of flavonol aglycones myricetin, quercetin, and kaempferol in Rhus coriaria L. using a monolithic column. In J. AOAC Int., 92(4) 1035-1043.

Mohammadi, A.; Pourreza, J.; Jalali, S. M. A.; Mirzaei, N. Khon (2011). Effect of Sumac Powder (Rhus Coriaria L.) And Probiotic on Performance of Broiler Chickens. Advances in Environmental Biology, 5 (8): 2409.

Mukherjee, A. K., Basu, S., Sarkar, N. and Ghosh, A. C. (2001) Advances in cancer therapy with plant based natural products. Curr. Med. Chem. 8, 1467-1486.

Özcan, M. and Akbulut, M. (2007). Estimation of minerals, nitrate and nitrite contents of medicinal and aromatic plants used as spices, condiments and herbal tea. In Food Chem., 106 (2) 852-858.

Özcan, M. and Haciseferogullari, H. (2004). A condiment sumac (Rhus coriaria L.) fruits Properties. Bulg. J. Plant. Physiol. 30, 74-84.

SAS. (1990). SAS/ STAT User's Guide, version 6, $4^{\text {th }}$ Edition. SAS Institute Inc, Cary, NC, USA. 
Sharbati A.A., Daneshyar, M. and Aghazadeh, A. (2013). Effects of different sumac seed powder on growth, blood metabolites and carcass characteristics of broiler chickens under heat stress condition. Animal Sciences Journal 97, 43-51.

Valiollahi M.R., Gholami M., NamjooA. R., Rahimian R. and Rafiee A. (2014). Effect of using Sumac (Rhus coriaria L.) and Ajwain (Trachyspermumcopticum) powders on performance and intestinal microbial population in broiler chicks. Res. Opin. Anim. Vet. Sci., 4(10): 545-549.

van Poppel, G. and van den Berg, H. (1997). Vitamins and cancer. Cancer Lett. 114, 195-202.

Zavaragh F. M.(2011).Influence of garlic and sumac powder (Rhus coriaria L.) on performance, carcass and blood biochemical of Japanese quails, Ann. Biol. Res., 2, 542-545.

\section{تأثير استخدام بذور السماق المطحونة فى العلائق كمضاد اكسدة ومنشط نمو على الأداء الانتاجى للسمان اليابانى}

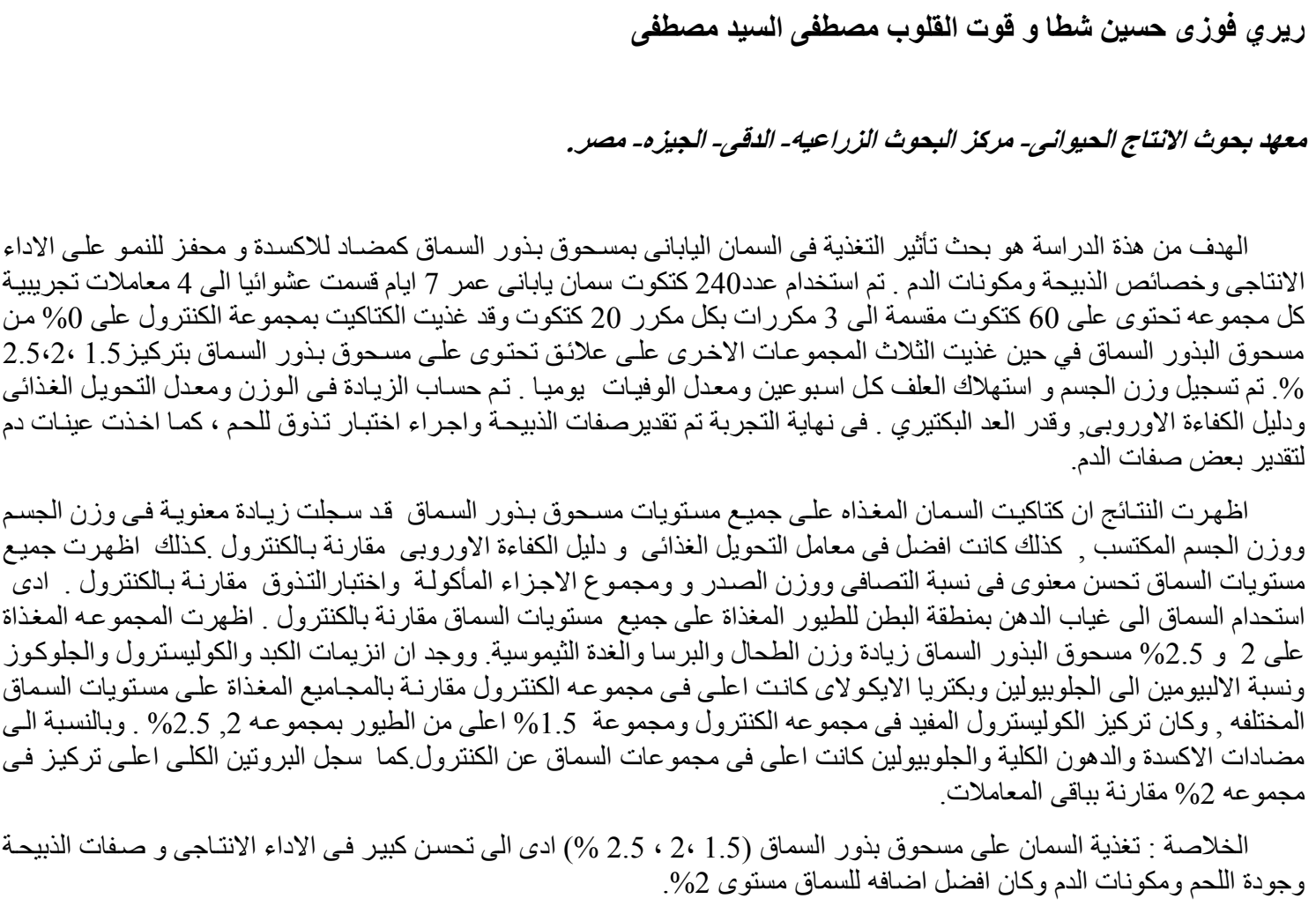

